\title{
RANCANG BANGUN APLIKASI SISTEM INFORMASI CHECKLIST INVENTORI TEKNOLOGI INFORMASI (STUDI KASUS: TELKOMSEL INDONESIA)
}

\author{
Ainnur Rofiq, Riansyah Halimi, Feby Artwodini Muqtadiroh, Raras Tyasnurita \\ Jurusan Sistem Informasi, Fakultas Teknologi Informasi, Institut Teknologi Sepuluh Nopember \\ Kampus Keputih, Sukolilo, Surabaya 60111 \\ Telp: (031) 5999944, Fax: (031) 5964965 \\ Email : rofiq@outlook.com
}

\begin{abstract}
Telkomsel is a subsidiary of Telkom Indonesia, the largest mobile telecommunications operator in Indonesia. In the business process, Telkomsel has many IT inventory that should be checked periodically and the data history of IT inventory must be stored. Management of Telkomsel see that business process run less effective because the recording process is still done manually. With so many inventory and branches spread all owned by Telkomsel, the need for a system that can integrate data checklist inventory available in each branch is important, so that when need to know current IT inventory conditions, Telkomsel had no trouble. Therefore, in this research had done development of Information System Application of Inventory Checklist to check inventory on a regular basis and see the history of the inventory data in real-time and integrated inter branch. With the information system, company can check the status of inventories to determine any inventory that conditions are unfavorable.The development result of Information System Application of Inventory Checklist is the company can check the inventory status within real time so that can help company know which inventory has work well or not. With this application is to be expected helping company know the condition about the IT inventory up to date and automatic.
\end{abstract}

\section{Abstrak}

Telkomsel merupakan anak perusahaan dari Telkom Indonesia yang merupakan operator telekomunikasi seluler terbesar di Indonesia. Dalam proses bisnisnya, Telkomsel mempunyai banyak inventori TI yang harus dilakukan pengecekan secara berkala dan data histori dari inventori TI tersebut harus disimpan. Pihak Manajemen Telkomsel memandang proses bisnis tersebut berjalan kurang efektif karena proses pencatatan tersebut masih dilakukan secara manual. Dengan jumlah inventori yang sangat banyak dan tersebar di semua kantor cabang yang dimiliki oleh Telkomsel, maka perlu adanya sebuah sistem yang dapat mengintegrasikan data-data checklist inventori yang ada di setiap cabang, sehingga saat membutuhkan data untuk mengetahui kondisi inventori TI saat ini, pihak Telkomsel tidak menemui kesulitan. Oleh karena itu, pada penelitian ini akan dilakukan pembuatan aplikasi Sistem Informasi Checklist Inventory (CYNTO) dengan menggunakan CodeIgniter untuk mengecek inventori secara berkala dan melihat data histori dari inventori secara real-time dan terintegrasi antar kantor cabang. Hasil yang didapatkan dari pembuatan aplikasi Sistem Informasi Checklist Inventory (CYNTO) adalah perusahaan dapat mengecek status inventorinya secara real-time sehingga dapat mengetahui inventori mana saja yang kondisinya kurang baik. Dengan pembuatan aplikasi tersebut diharapkan dapat membantu pihak perusahaan dalam mengetahui kondisi inventori ITnya secara terkini dan otomatis.

Kata kunci : checklist, inventori, sistem informasi.

\section{PENDAHULUAN}

Telkomsel merupakan perusahaan operator telekomunikasi seluler terbesar di Indonesia dengan layanan pascabayarnya yang diluncurkan pada tanggal 26 Mei 1995. Dalam proses bisnisnya, Telkomsel memiliki banyak inventori Teknologi Informasi (TI) yang telah dilakukan pengecekan secara berkala kondisinya dan data histori dari inventori TI tersebut. Pihak
Manajemen Telkomsel memandang proses bisnis tersebut berjalan kurang efisien karena masih dilakukan pencatatan manual. Manajemen menginginkan sistem informasi checklist inventori secara real-time dimana setiap waktu data inventori dapat dilihat, apakah kondisinya sedang dalam kondisi baik atau kurang baik. Selain itu juga diinginkan adanya data pencatatan berkala dari inventori TI tersebut. Untuk 
Rofiq, dkk., Rancang Bangun Aplikasi Sistem Informasi Checklist Inventori...

menanggulangi permintaan tersebut, dalam penelitian ini dilakukan perancangan dan pembangunan sistem informasi checklist inventori TI di Telkomsel. Batasan permasalahan dalam pembuatan aplikasi adalah sebagai berikut:

- Perancangan, pembangunan serta implementasi sistem informasi checklist inventory TI hanya untuk modul perangkat, kategori asset, asset, pengelolaan pengguna, pengelolaan kantor dan checklist.

- Checklist yang dilakukan pada aplikasi ini terbatas pada inventori TI saja.

\section{METODOLOGI}

Untuk melakukan penelitian ini, dibutuhkan sebuah aplikasi berbasis web yang lengkap dengan koneksi pada database untuk pencatatan berkala secara online. Oleh karena itu, teknologi yang digunakan dalam penelitian ini adalah basis data pada MySql dengan pemrograman berbasis code igniter.

Basis data adalah kumpulan informasi yang disimpan di dalam komputer secara sistematik sehingga dapat diperiksa menggunakan suatu program komputer untuk memperoleh informasi dari basis data tersebut. Perangkat lunak yang digunakan untuk mengelola data disebut sebagai manajemen basis data (Haryanto, Imam \& Raharjo, Imam, 2009).

MySQL adalah salah satu implementasi dari sistem manajemen basis data relasional (RDBMS) yang didistribusikan secara gratis dibawah lisensi GPL (General Public License). Setiap pengguna dapat secara bebas menggunakan MySQL, namun dengan batasan perangkat lunak tersebut tidak boleh dijadikan produk turunan yang bersifat komersial (Miftakhul, Huda, 2010).

CodeIgniter adalah kerangka kerja yang digunakan untuk pengembangan perangkat lunak menggunakan bahasa pemrograman PHP. CodeIgniter adalah aplikasi open source yang berupa kerangka kerja dengan model MVC (Model, View, Controller) yang pada umumnya digunakan untuk membangun website dinamis. Konsep MVC CodeIgniter ditunjukkan pada gambar 1. CodeIgniter memudahkan developer untuk membuat aplikasi web dengan cepat dan mudah dibandingkan dengan membuatnya dari awal, karena sudah disediakan paket-paket yang diperlukan untuk mengembangkan website lebih lanjut (Basuki, 2010).

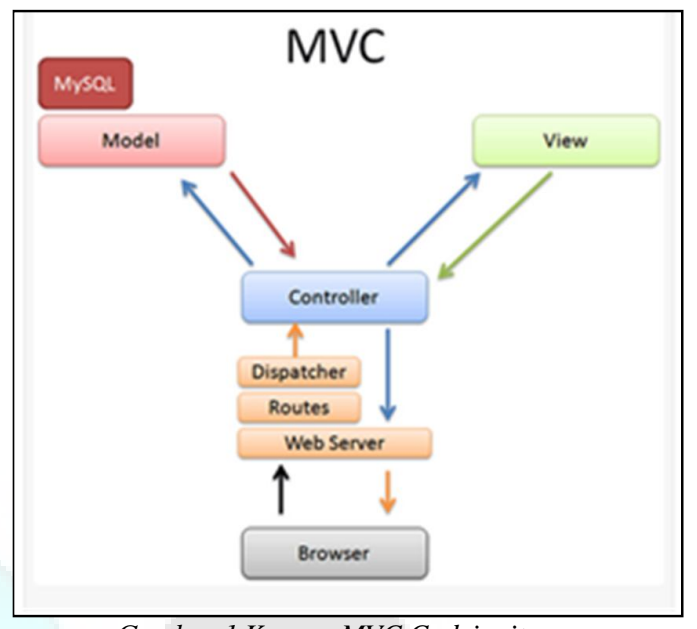

Gambar 1 Konsep MVC Codeigniter

\subsection{Checklist Inventori}

Checklist adalah daftar yang mencakup faktorfaktor yang ingin diselidiki (Bimo Walgito, 1985). Menurut Sutrisno Hadi (1990) checklist adalah suatu daftar nama-nama subjek dan faktor-faktor yang akan diselidiki. Check list merupakan daftar yang berisi unsur-unsur yang mungkin terdapat dalam situasi atau tingkah laku atau kegiatan individu yang diamati (Fransiska, I.Y, 2009). Dari pernyataan diatas, dapat disimpulkan bahwa inventori yang dimaksud adalah daftar-daftar yang berisi beberapa subjek yang akan diteliti. Dalam hal ini subjek yang diteliti yaitu perangkat teknologi informasi yang dipunyai oleh perusahaan. Dalam checklist inventori tersebut akan diberi keterangan apakah kondisi inventori IT tersebut dalam kondisi baik, rusak, maupun dalam kondisi perawatan.

\subsection{Pemodelan Usecase dengan UML}

UML merupakan bahasa standar yang digunakan dalam menentukan, visualisasi, membangun, dan mendokumentasikan artifact sistem perangkat lunak (IBM, 1997).

\section{Use Case Diagram}

Diagram use case adalah salah satu diagram yang digunakan untuk memodelkan perilaku sistem dan merupakan pusat pemodelan perilaku sistem, subsistem dan kelas. Masing-masing diagram use case menunjukan sekumpulan use case, aktor dan hubungannya (Bambang, 2004). 


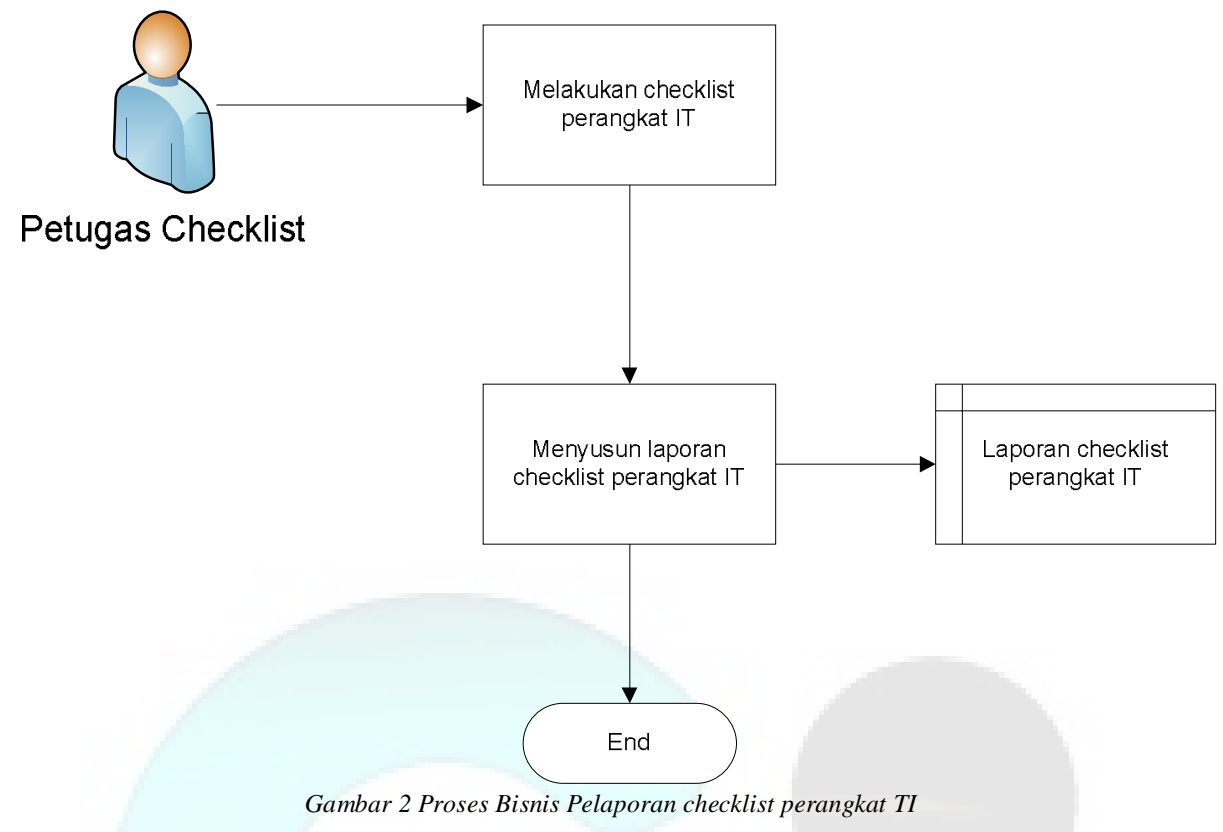

Tujuan utama pemodelan use case adalah (Bambang, 2004):

a. Memutuskan dan mendeskripsikan kebutuhan-kebutuhan fungsional sistem.

b. Memberikan deskripsi jelas dan konsisten dari apa yang seharusnya dilakukan, sehingga model use case digunakan diseluruh proses pengembangan untuk mengacu sistem harus memberikan fungsionalitas yang dimodelkan pada use case.

c. Menyediakan basis untuk melakukan pengujian sistem yang memverifikasi sistem.

d. Menyediakan kemampuan melacak kebutuhan fungsional menjadi kelas-kelas dan operasi-operasi aktual di sistem.

\section{HASIL dan PEMBAHASAN}

Hasil dari sistem informasi checklist inventori ini akan dibahas dalam beberapa sub bab. Pada awalnya akan dibahas terlebih dahulu mengenai alur checklist perangkat TI lalu pemetaan kondisi saat ini dengan kondisi setelah diterapkannya sistem informasi checklist pada Telkomsel.

\subsection{Alur Checklist Perangkat TI dan Pelaporan Perangkat TI pada Telkomsel}

Pencatatan checklist perangkat TI yang dilaksanakan di kantor oleh staff TI dicatat ke dalam lembar checklist yang ada. Sistem pencatatan ini dinilai kurang efektif karena memiliki beberapa kelemahan antara lain:

- Kemungkinan hilang/rusaknya hasil checklist.

- Adanya kesalahan data perangkat yang dichecklist. Misalnya saja ada sebuah perangkat yang sama, namun ditulis dengan nama yang berbeda. Hal ini akan sangat membingungkan saat pelaporan.

- Kesulitan dalam mencari data riwayat dari perangkat tertentu. Dengan begitu banyaknya catatan hasil checklist yang telah dilakukan, maka dapat dipastikan sangat sulit dalam mencari data pencatatan riwayat dari sebuah perangkat TI.

Setelah seorang staff TI melakukan checklist, maka staff TI tersebut harus membuat laporan untuk diserahkan kepada Supervisor IT. Ada dua kelemahan dalam sistem manual ini:

- Staff TI harus melakukan dua kali kerja, yaitu menuliskan hasil checklisnya dan menyusun laporan dari hasil checklisnya

- Supervisor TI tidak dapat melihat laporan checklist tersebut sewaktu-waktu dan termutakhirkan secara otomatis.

Proses bisnis pelaporan checklist perangkat TI dimulai dari monitoring inventori IT apa saja yang telah dimiliki oleh perusahaan. Kemudian dilakukan pelaporan terkait dengan kondisi terkini inventori IT yang dipunyai yang ditunjukkan pada gambar 2. 
Rofiq, dkk., Rancang Bangun Aplikasi Sistem Informasi Checklist Inventori...

Tabel 1 Mapping Kondisi Saat Ini dan Akan Datang

\begin{tabular}{ccc}
\hline Kondisi saat ini & Kondisi diharapkan & Overview solusi \\
\hline Proses pencatatan dan pengecekan checklist inventori TI & Pengelolaan pencatatan & Sistem informasi \\
masih dilakukan secara manual. Dengan kondisi berikut: & dan pengecekan & berbasis web \\
$\checkmark$ Proses pencatatan dan pengecekan checklist inventori & checklist inventori TI & dengan \\
TI masih secara manual (menggunakan kertas). & yang terintegrasi dan & menggunakan \\
$\checkmark$ Proses pelaporan hasil pengecekan dan pencatatan & pelaporan hasil checklist & server lokal. \\
tidak bisa dilakukan secara real time. & secara real time & \\
\hline
\end{tabular}

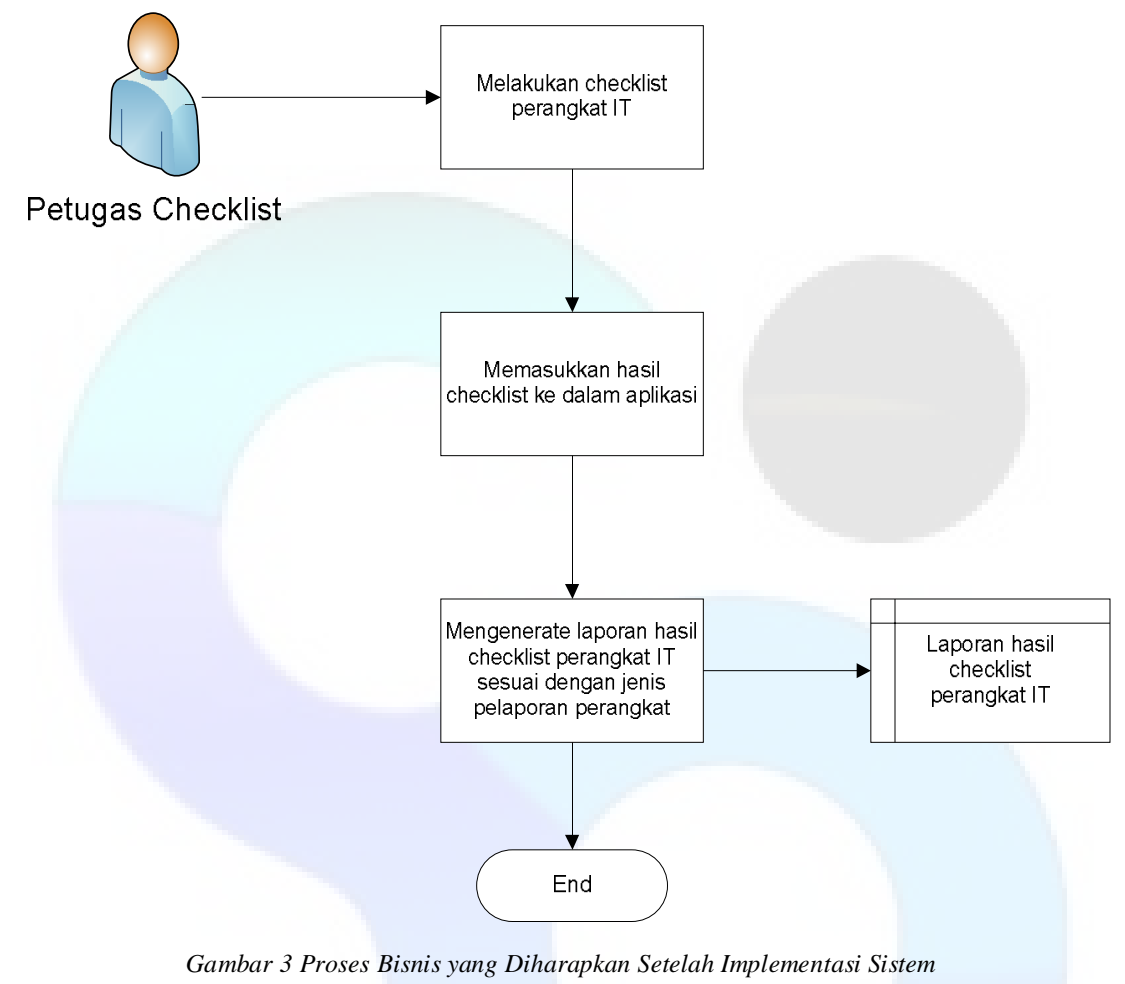

\subsection{Pemetaan Kondisi Saat Ini dan Kondisi Akan Datang}

Harapan dari Telkomsel adalah pelaksanaan pencatatan perangkat TI secara digital serta data perangkat TI yang ada pada semua kantor cabang tersimpan di database. Hal ini dimaksudkan agar tidak ada lagi data yang terduplikasi dan memudahkan akses sewaktu-waktu oleh pengguna yang memiliki kewenangan tersebut. Proses bisnis yang diharapkan ke depan setelah implementasi sistem ditunjukkan pada gambar 3 dan tabel 1 .

Implementasi dari rancangan ini secara garis besar terdapat 7 jenis pelaporan yang akan digenerate oleh sistem dengan detail isi laporan ditunjukkan pada gambar 4 sampai dengan gambar 10 pada lampiran.

\subsection{Desain dan implementasi}

Tujuan utama dari diagram use case adalah untuk menunjukkan apa yang dilakukan fungsi sistem oleh aktor. Aktor pada sistem informasi checklist ini terbagi menjadi dua, yaitu administrator dan petugas checklist.

Administrator adalah user yang memiliki kewenangan penuh, termasuk untuk membuat dan menghapus user yang ada. Sedangkan petugas checklist adalah petugas yang hanya dapat mengakses menu Checklist Visiting saja. Peran administrator dalam sistem ditunjukkan pada gambar 11 sampai dengan gambar 17, dan pengguna ditunjukkan pada gambar 18 dan 19.

Pada gambar 11 ditunjukkan use case diagram pada saat pengguna masuk ke dalam sistem melalui fitur login. Sistem ini memiliki fitur untuk autentifikasi pengguna dimana pengguna memiliki dua pilihan di awal yaitu login atau logout. 
Pada proses login, terdapat proses pengenalan apakah user tersebut pengguna biasa atau administrator. Bila pengguna tersebut adalah administrator maka ia akan memiliki empat fitur utama yaitu membuat user baru, melihat daftar user yang telah tersimpan pada sistem, mengubah atribut dari user dan menghapus user yang ditunjukkan oleh Gambar 12.

Selain pada fungsionalitas utama, administrator juga memiliki fungsionalitas office management dan manajemen perangkat. Office management yaitu untuk membuat, melihat, memutakhirkan, menghapus kantor dan melihat daftar perangkat yang tersimpan dalam database seperti yang ditunjukkan pada gambar 13. Sedangkan fungsionalitas manajemen perangkat memiliki kemampuan untuk menambah, melihat, memutakhirkan dan menghapus master perangkat serta melihat item pekerjaan seperti yang ditunjukkan pada gambar 14. Administrator juga bertanggungjawab atas pengaturan kategori aset. Administrator dapat melakukan tambah, lihat, pemutakhiran dan penghapusan kategori aset yang telah tersimpan seperti yang ditunjukkan pada Gambar 15.

Fungsionalitas Checklist Inventory dimiliki oleh user. Fungsionalitas ini meliputi membuat, mengubah dan mencetak checklist inventory. Kesemua fitur ini termasuk fitur pelaporan hasil checklist inventory.

Gambar 17 menunjukkan desain database yang dibutuhkan untuk membangun sistem ini. Database terdiri dari 13 tabel yang berkorelasi satu dengan yang lainnya.

\subsection{Uji Coba dan Hasil Implementasi}

Hasil uji coba dan implementasi dari sistem ditunjukkan pada gambar 18 sampai dengan gambar 26. Pada halaman login (gambar 18), jika user salah dalam memasukkan username dan password, maka sistem akan memberikan pemberitahuan. Pada halaman pengelolaan user (gambar 19), user dimungkinkan untuk melihat, membuat, memperbarui dan menghapus data user yang bisa mengakses aplikasi ini. Pada menu yang sama juga terdapat validasi saat menambahkan user baru sesuai dengan mandatori informasi yang harus diisi (gambar 20). Pada aplikasi ini terdapat dua jenis pengguna, administrator dan petugas checklist. Gambar 21 dan Gambar 22 menunjukkan hasil uji coba dengan kedua jenis user tersebut. Terlihat bahwa kedua jenis pengguna memiliki fitur yang berbeda sesuai dengan fungsi masingmasing pengguna.

Kemampuan user untuk mengelola data master kantor yang dimiliki oleh kantor, lengkap dengan alamat dan nomor telpon dari kantor tersebut ditunjukkan oleh Gambar 23. Sedangkan pada gambar 24 menunjukkan bahwa user dapat membuat kunjungan dan checklist dari inventori TI yang diperiksa. User tidak hanya dapat membuat kunjungan namun juga dapat mengunduh report checklist seperti yang ditunjukkan pada gambar 25 .

Sistem ini juga dilengkapi dengan menu pencarian ada pada setiap modul, diantaranya pengelolaan pengguna, pengelolaan pengelolaan asset dan pengelolaan kunjungan (gambar 26).

\section{SIMPULAN dan SARAN}

Kesimpulan yang dapat diambil dari penelitian ini adalah Aplikasi CYNTO terbukti dapat membantu pihak Telkomsel terutama pada bagian TI untuk memperlancar dalam mengecek perangkat TI yang dimiliki dibandingkan dengan proses manual.

Saran untuk penelitian adalah dalam proses pembuatan aplikasi, dimana ada baiknya untuk membuat identifikasi kebutuhan di awal yang jelas agar tidak kesulitan dalam proses pembuatan aplikasi. Selain itu, untuk ke depannya dapat dikembangkan pula modul lain yang terkait dengan checklist perangkat TI sehingga dapat meningkatkan proses bisnis yang terkait dengan checklist perangkat TI.

\section{DAFTAR RUJUKAN}

Bambang Heriyanto. 2004. Rekayasa Sistem Berorientasi Objek. Bandung: Informatika

Basuki, Awan Pribadi. 2010. Membangun Web Berbasis PHP dengan Framework Codeigniter. Yogyakarta: Lokomedia.

Heryanto, Imam \& Raharjo, Imam. 2009. Menguasai Oracle, SQl, dan PLSQL. Bandung: Informatika.

Miftakhul, Huda. 2010. Membuat Aplikasi Database dengan Java, MySQL dan Netbeans. Yogyakarta: Kompas Gramedia.

Fransiska, I. Y. 2009. Inventory Control dan Perencanaan Bahan Baku di Industri Manufakturing Pada PT. Indofood Sukses Makmus. Medan.

IBM. 1997, International Business Machine. 1982.http://www-

01.ibm.com/software/rational/uml/ [14 Agustus 2011].

Sutrisno Hadi. 1991. Sesi Program Stastitik. Yogyakarta: UGM

Bimo Walgito. 1991. Pengantar Psikologi Umum. Yogyakarta: Andi Offset. 
Rofiq, dkk., Rancang Bangun Aplikasi Sistem Informasi Checklist Inventori...

\section{LAMPIRAN TAMPILAN SISTEM CYNTO}

Tanggal Kunjungan : Loker Pengecekan : jember

Checklist Kunjungan Perangkat Datacomm

\begin{tabular}{|c|c|c|c|c|}
\hline & & & Status & Domot c > \\
\hline NO & Item Pekerjaan & ID Asset/SN \#/User ID & (OK/not OK) & Remarks \\
\hline 1 & Check Koneksi LAN (sample) & & & OK : connected, not OK : not connected \\
\hline 2 & Check Kecepatan Koneksi LAN & & & Kecptan Download: $\quad$ Upload: \\
\hline 3 & Status Router & 21987916 & & \\
\hline 4 & Status Bluecoat & & & \\
\hline 5 & Status Catalyst & FOC01252V3WN/FOC1443W7LL & & \\
\hline 6 & Status Catalyst & FOC1443VONN & & \\
\hline 7 & Status Catalyst & & & \\
\hline
\end{tabular}

\begin{tabular}{|l|l|}
\hline Item Pekerjaan & Jmh \\
\hline $\begin{array}{l}\text { Jumlah LAN yang terkoneksi via } \\
\text { PC }\end{array}$ & \\
\hline $\begin{array}{l}\text { Jumlah LAN yang terkoneksi via } \\
\text { Laptop }\end{array}$ & \\
\hline Jumlah Karyawan Tetap & \\
\hline Jumlah Karyawan Outsource & \\
\hline
\end{tabular}

Pelaksana,

Mengetahui,

User Grapari,

(Staff Ir Office Automation Support)

(Spv. IT Office Automation Support)

(Spv. Shop Pelayanan)

Gambar 4 Laporan Kunjungan Perangkat Datacomm

Tanggal Kunjungan :

Loker Pengecekan :

UPS ID

Checklist Kunjungan Perangkat UPS

\begin{tabular}{|c|l|l|l|l|}
\hline \multirow{2}{*}{ NO } & \multicolumn{2}{|c|}{ Item Pekerjaan } & \multicolumn{1}{c|}{ Status } & \multicolumn{2}{c|}{ Remarks } \\
\cline { 3 - 4 } & & (OK/not OK) & \multicolumn{2}{|c}{} \\
\hline 1 & Status Grounding & & Ada/tdk & \\
\hline 2 & Status UPS & & Normal/alarm & \\
\hline & & & & \\
\hline & & & & \\
\hline
\end{tabular}

Pelaksana,

Mengetahui,

User Grapari,

(Staff IT Office Automation Support)

(Spv. IT Office Automation Support)

(Spv. Shop Pelayanan)

Gambar 5 Laporan Kunjungan Perangkat UPS

Tanggal Kunjungan :
Loker Pengecekan :

Checklist Kunjungan Computer Room

\begin{tabular}{|c|l|c|l|c|}
\hline \multirow{2}{*}{ NO } & \multirow{2}{*}{ Item Pekerjaan } & \multicolumn{1}{|c|}{ Status } & \multicolumn{2}{c|}{ Remarks } \\
\cline { 3 - 5 } & & (OK/not OK) & \multicolumn{1}{|c|}{ Parameter } & \\
\hline 1 & Status AC & & Dingin/panas (C) & \\
\hline 2 & Status Kebersihan & & Bersih/Kotor & \\
\hline 3 & Status Kerapihan & & Rapih/Berantakan & \\
\hline 4 & & & & \\
\hline
\end{tabular}

Pelaksana,

Mengetahui,

User Grapari,

(Staff IT Office Automation Support) 
Jurnal Sistem Informasi, Volume 4, Nomor 5, September 2013, hlm 310-322

Tanggal Kunjungan :

Loker Pengecekan :
PABX ID :

Checklist Kunjungan Perangkat PABX

\begin{tabular}{|c|l|c|c|}
\hline \multirow{2}{*}{ NO } & \multicolumn{1}{|c|}{ Item Pekerjaan } & Status & \multirow{2}{*}{ Remarks } \\
& & (OK/not OK) & \\
\hline 2 & Check Koneksi Line telpon antar ekstension & & \\
\hline 3 & Check Koneksi telpon outgoing & & \\
\hline 4 & Check Koneksi telpon incoming & & \\
\hline 5 & Status PABX & & \\
\hline
\end{tabular}

Pelaksana,

Mengetahui,

User Grapari,

(Staff Ir Office Automation Support)

(Spv. IT Office Automation Support)

(Spv. Shop Pelayanan)

Gambar 7 Laporan Kunjungan Perangkat PABX

Tangsal Kunjuazen :

Loter Pengectian :

Checklist Kunjungan Perangkat Desktop

\begin{tabular}{|c|c|c|c|c|c|c|c|c|}
\hline \multirow{2}{*}{ no } & \multirow{2}{*}{ Isem Noberjasn } & \multirow{2}{*}{ Ausut Tas } & \multirow{2}{*}{ Moutname } & \multirow{2}{*}{$\begin{array}{l}\text { Unername } \\
\text { Domain }\end{array}$} & \multirow{2}{*}{ Nation } & \multirow{2}{*}{$\frac{\text { Menuk }}{\text { [Ox/mot Ox) }}$} & \multirow{2}{*}{$\frac{\text { Shatus }}{\text { (finiah/not tinihh }}$} & \multirow{2}{*}{ Memarks } \\
\hline & & & & & & & & \\
\hline 1 & Check aplikavi : (sample denktop) & & & & & & & \\
\hline & -chedk Login & 06 & 4 & b & & & & \\
\hline & 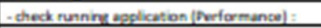 & & & & & & & \\
\hline & A. Cookin & & & & & & & \\
\hline & b.oes & & & & & & & \\
\hline & coasis & & & & & & & \\
\hline & d. Paradhe & & & & & & & \\
\hline & c. hamedy If via wes & & & & & & & \\
\hline & f.Aplibailocat Regionel & & & & & & & \\
\hline & $2.00 \mathrm{p} /$ Mreti & & & & & & & \\
\hline & hams & & & & & & & \\
\hline & i wes HUM & & & & & & & \\
\hline & $+\ldots$ & & & & & & & \\
\hline & & & & & & & & \\
\hline 2 & Check Danktog (lampla denitop) & & & & & & & \\
\hline & - chedk kentbi WN & & & & & & & \\
\hline & - check join domain & & & & & & & \\
\hline & 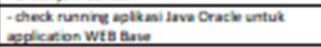 & & & & & & & \\
\hline & - chedk running active If urtuk apl hani arrica & & & & & & & \\
\hline & - chedk antivins" & & & & & & & \\
\hline & - check waer 2 paumord VWK & & & & & & & \\
\hline & - check konfinurai emai & & & & & & & \\
\hline & -ched os Windion & & & & & & & \\
\hline & - check Marronofi Offica & & & & & & & \\
\hline & - check beal addrens 8 grergy & & & & & & & \\
\hline & - ched creste groflie user & & & & & & & \\
\hline
\end{tabular}

Gambar 8 Laporan Kunjungan Perangkat Desktop

Tanggal Kunjungan :

Loker Pengecekan :

\section{Checklist Kunjungan Perangkat Wifi}

\begin{tabular}{|c|c|c|c|}
\hline \multirow{2}{*}{ NO } & \multirow{2}{*}{ Item Pekerjaan } & Status & \multirow{2}{*}{ Remarks (dgn proxy/tanpa proxy) } \\
\hline & & (OK/not OK) & \\
\hline 1 & i-zone - Intranet & & \\
\hline 2 & i-zone -Internet & & \\
\hline 3 & d-zone-Internet & & \\
\hline 4 & & & \\
\hline 5 & & & \\
\hline
\end{tabular}

Pelaksana,

Mengetahui,

User Grapari, 
Rofiq, dkk., Rancang Bangun Aplikasi Sistem Informasi Checklist Inventori...

Tanggal Kunjungan :

Loker Pengecekan

Checklist Kunjungan Perangkat Lain-lain

\begin{tabular}{|c|c|c|c|c|}
\hline \multirow{2}{*}{ No } & \multirow{2}{*}{ Item Pekerjaan } & \multirow{2}{*}{ ID Asset/SN \# } & Status & \multirow{2}{*}{ Remarks } \\
\hline & & & (OK/not OK) & \\
\hline 1 & Finger Print Computer Room & & & \\
\hline 2 & My Q (mesin antrian) & & & \\
\hline 3 & HUB \# 1 & & & \\
\hline 4 & HUB \#2 & & & \\
\hline 5 & HUB \#3 & & & \\
\hline 6 & HUB H4 & & & \\
\hline 7 & HUB \#5 & & & \\
\hline
\end{tabular}

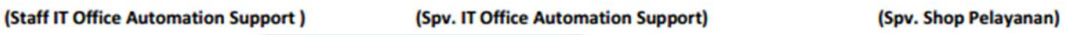
Gambar 10 Laporan Kunjungan Perangkat Lain-lain

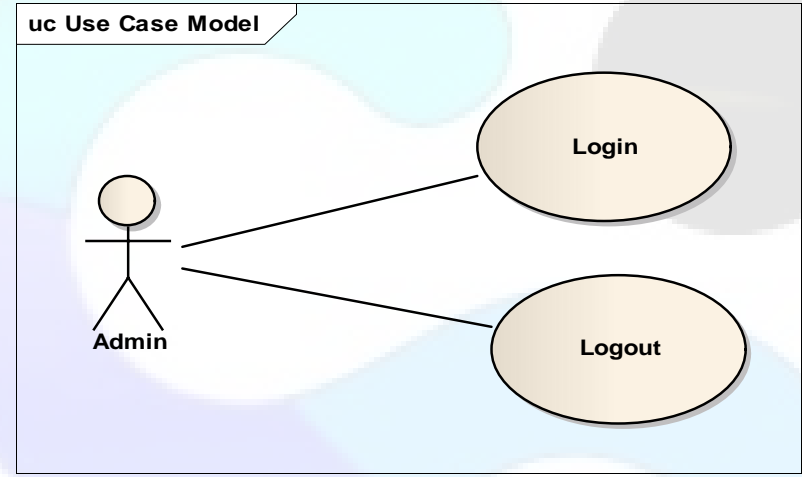

Gambar 11 Fungsi autentifikasi admin

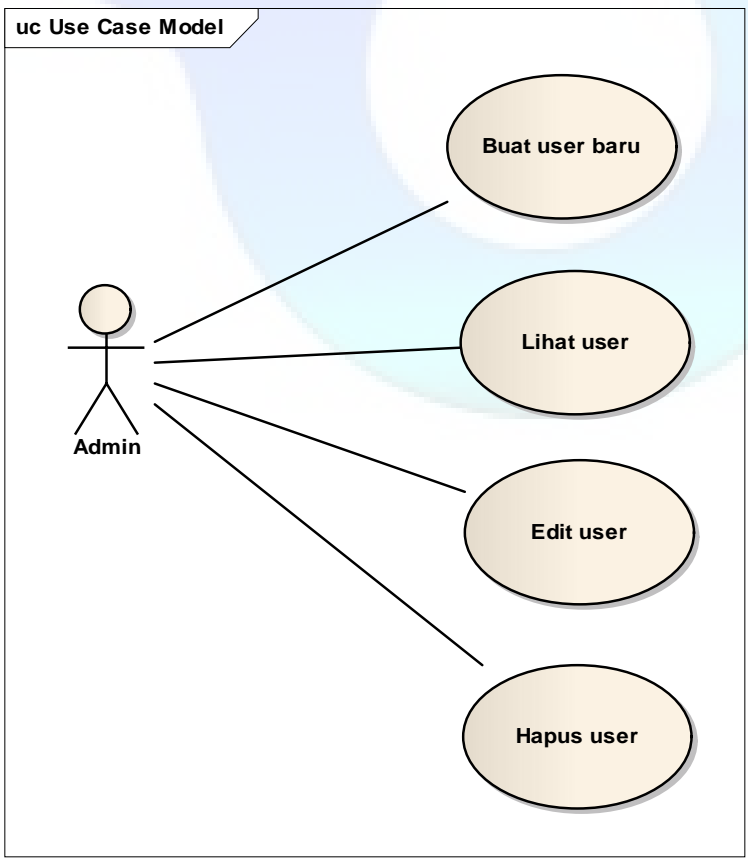

Gambar 12 Fungsionalitas manajemen admin 
Jurnal Sistem Informasi, Volume 4, Nomor 5, September 2013, hlm 310-322

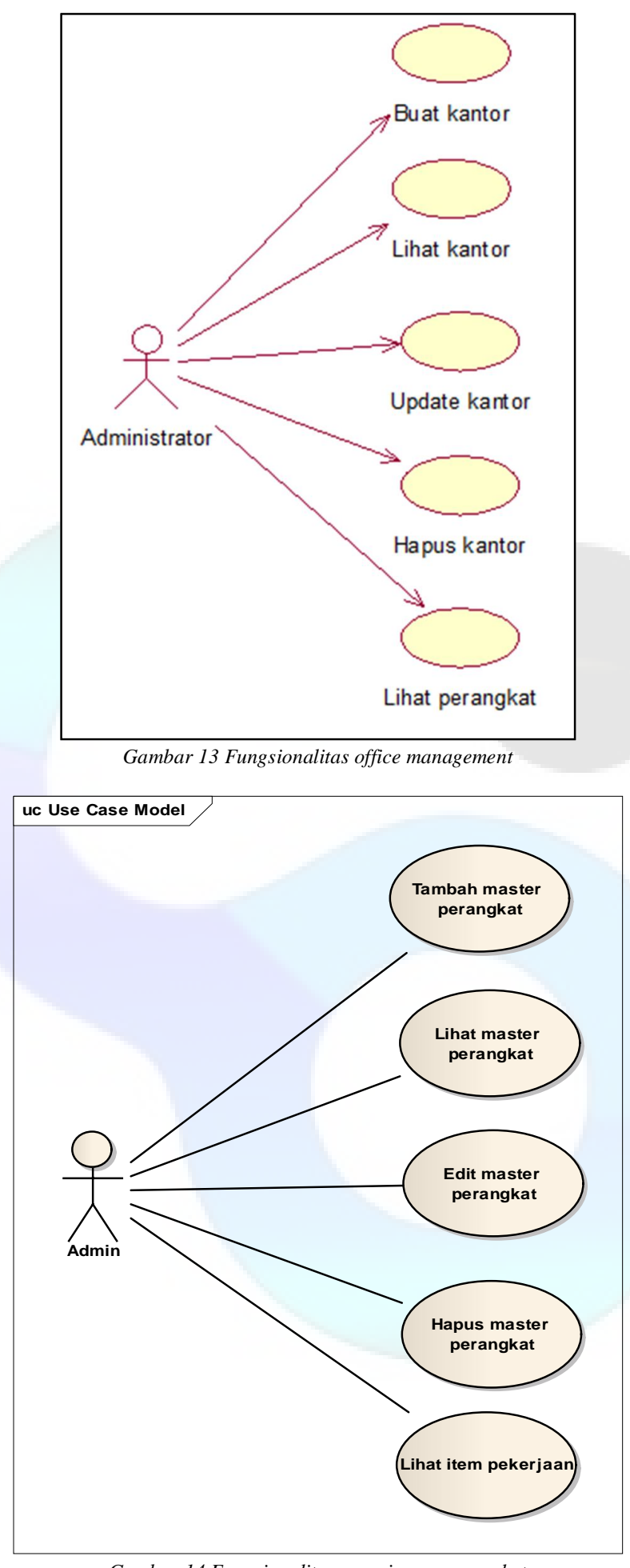

Gambar 14 Fungsionalitas manajemen perangkat 
Rofiq, dkk., Rancang Bangun Aplikasi Sistem Informasi Checklist Inventori...

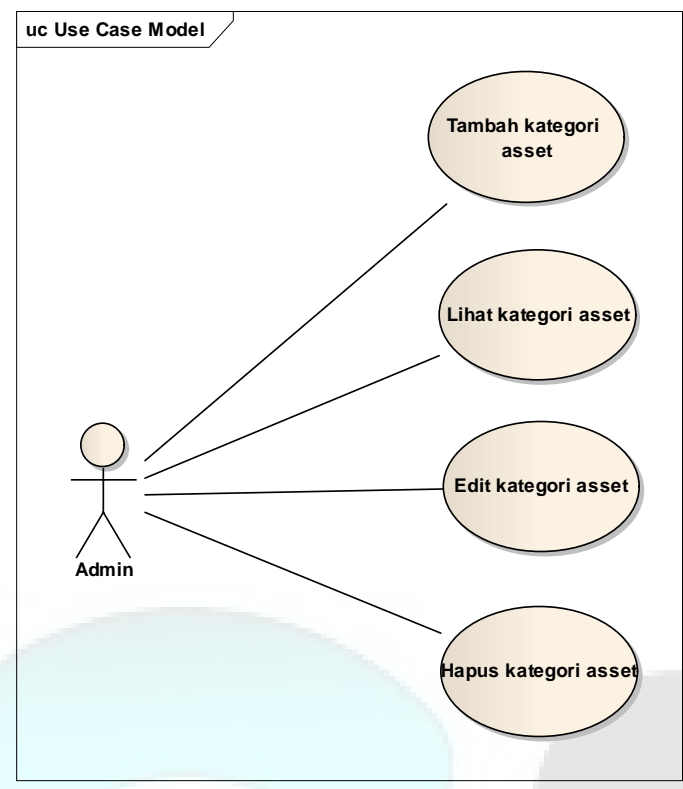

Gambar 15 Fungsionalitas manajemen kategori asset

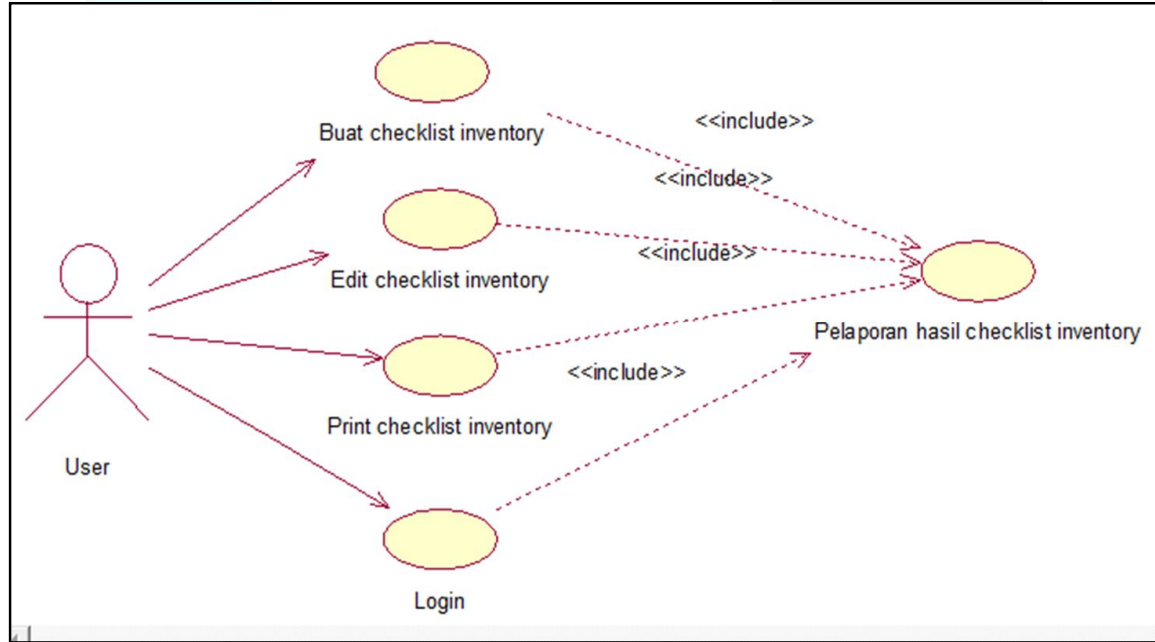

Gambar 16 Fungsionalitas Checklist Inventory

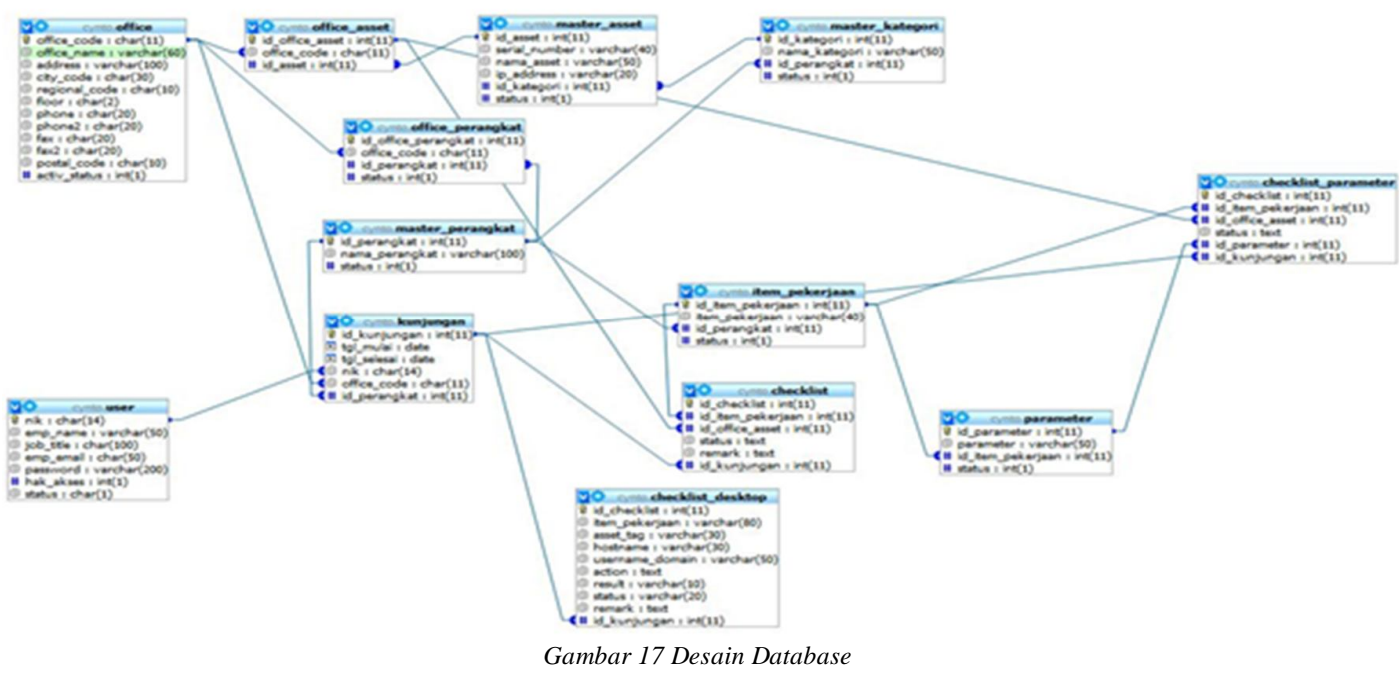


Jurnal Sistem Informasi, Volume 4, Nomor 5, September 2013, hlm 310-322

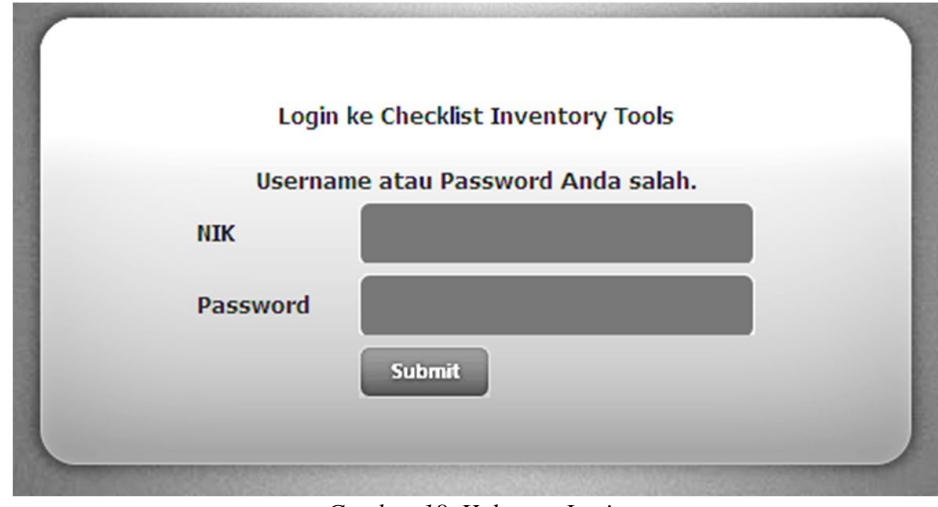

Gambar 18. Halaman Login
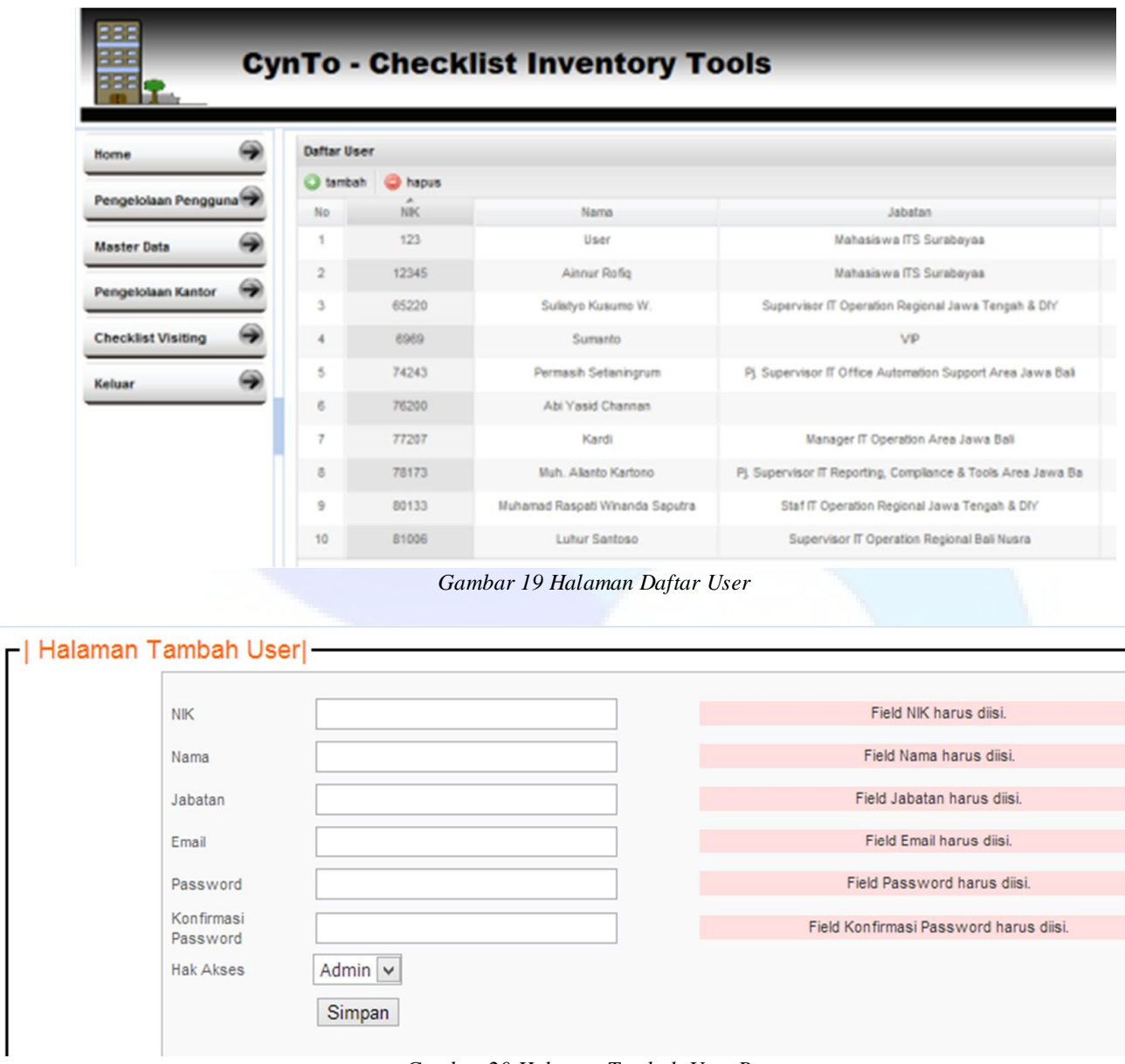

Field Password harus disi.

Field Konfirmasi Password harus disi.

$\operatorname{Admin} \vee$

Simpan

Gambar 20 Halaman Tambah User Baru
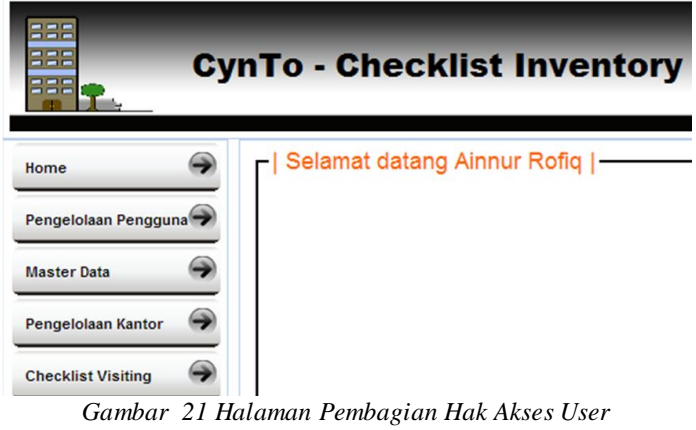

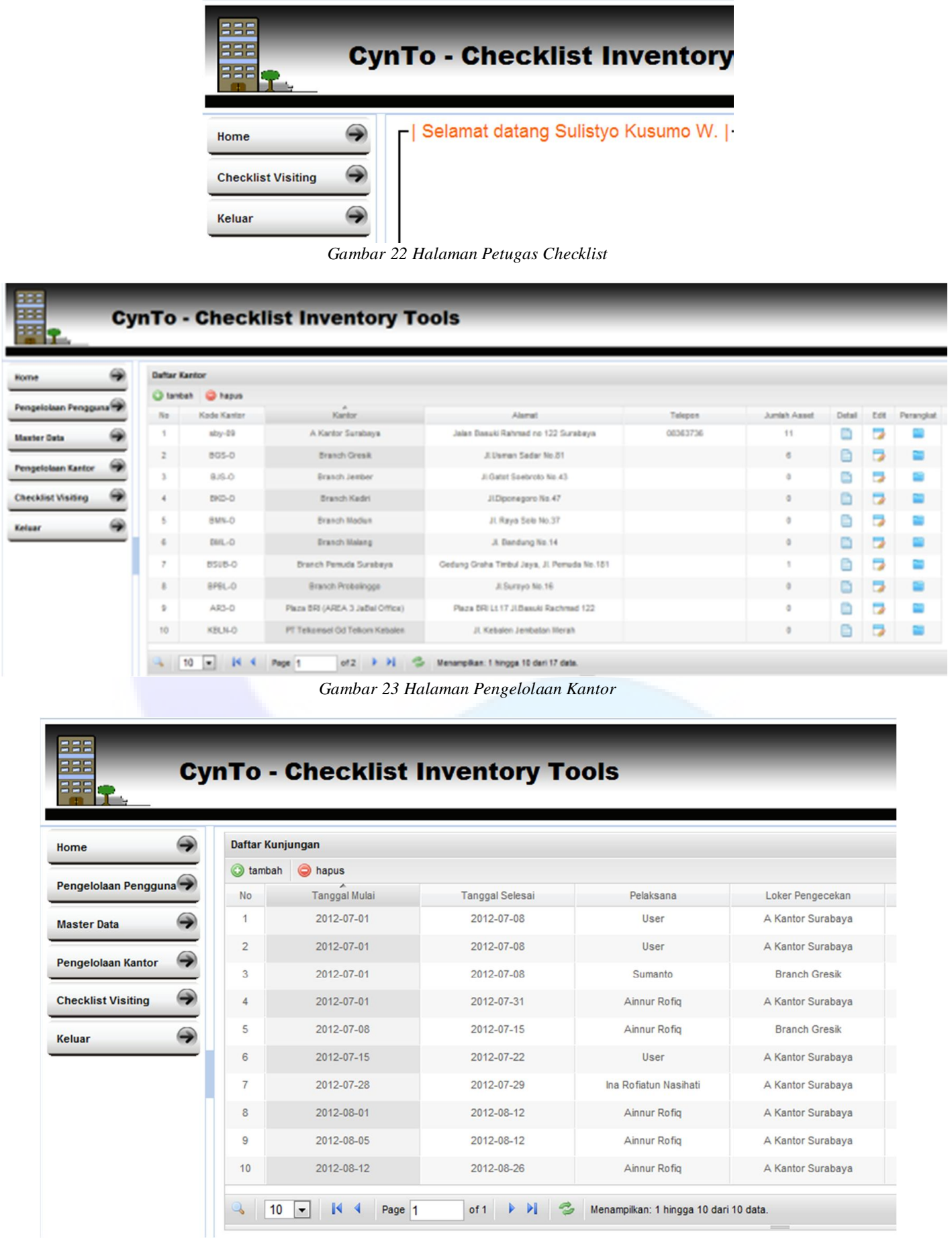

Gambar 24 Halaman Pengelolaan Checklist 
Jurnal Sistem Informasi, Volume 4, Nomor 5, September 2013, hlm 310-322

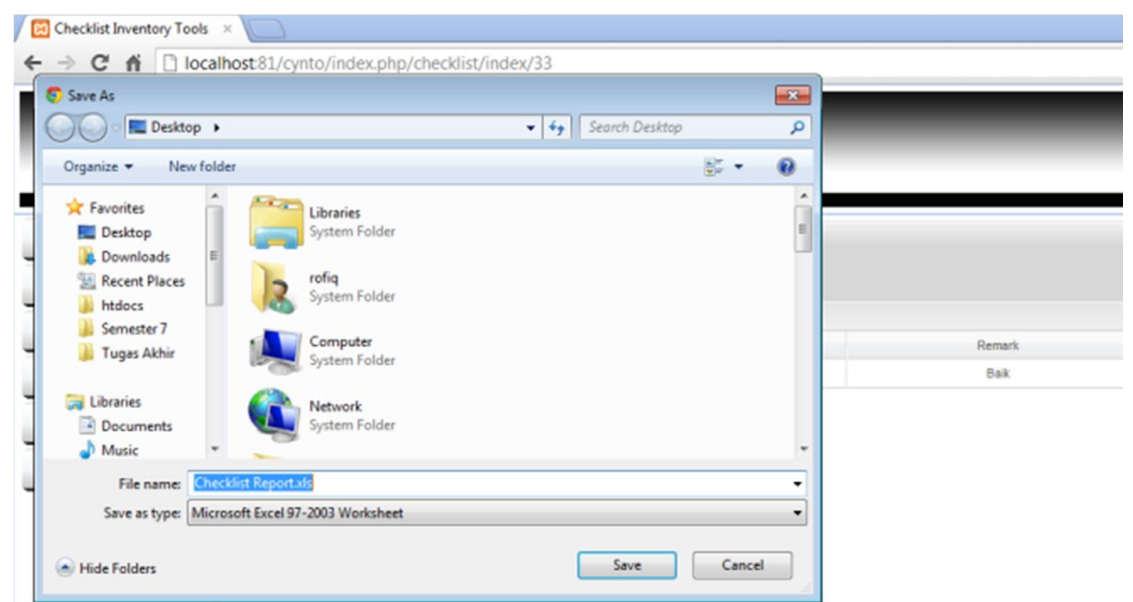

Gambar 25 Download Report Checklist

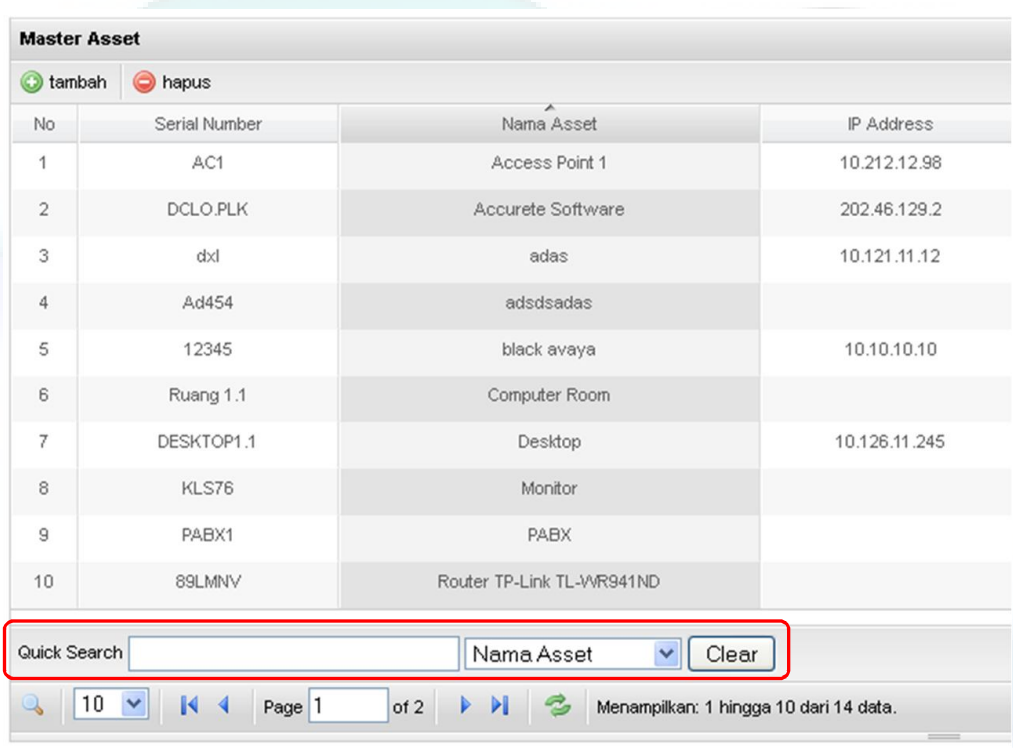

Gambar 26 Menu Pencarian 